The Confounding Island 



\title{
The Confounding Island
}

\author{
Jamaica and the Postcolonial Predicament
}

\author{
Orlando Patterson
}

The Belknap Press of Harvard University Press

Cambridge, Massachusetts

London, England

2019 
Copyright $(C) 2019$ by the President and Fellows of Harvard College

All rights reserved

Printed in the United States of America

First printing

Jacket illustration: Nalo Hopkinson

Jacket design: Lisa Roberts

$$
\begin{gathered}
978067424307 \text { I }(\mathrm{EPUB}) \\
9780674243088(\mathrm{MOBI}) \\
9780674243064(\mathrm{PDF})
\end{gathered}
$$

The Library of Congress has cataloged the printed edition as follows:

Names: Patterson, Orlando, I940- author.

Title: The confounding island : Jamaica and the postcolonial predicament / Orlando Patterson.

Description: Cambridge, Massachusetts : The Belknap Press of Harvard University Press, 2019. I Includes bibliographical references and index.

Identifiers: LCCN 2019015063 | ISBN 9780674988057

Subjects: LCSH: Postcolonialism-Jamaica. I Nationalism and sports-Jamaica. I Reggae music_Jamaica. I Urban poor-Jamaica. |

Jamaica-Social conditions. I Jamaica-Economic conditions.

Classification: LCC HN223.5 .P37 2019 I DDC 306.097292-dc23

LC record available at https://lccn.loc.gov/20I90I 5063

Excerpt from "Islands" from IN A GREEN NIGHT by Derek Walcott. Copyright (C) I962 by Derek Walcott.

Reprinted by permission of Farrar, Straus and Giroux. 
For Anita

and for Kaia, Barbara, and Rhiannon 

But islands can only exist

If we have loved in them.

-Derek Walcott

I shall return again; I shall return

To laugh and love and watch with

wonder-eyes

-Claude McKay 
